\title{
Effect of age and season on the thyroid hormone activity of Mizoram strain female mithun (Bos frontalis)
}

\author{
Lalsangpuii ${ }^{1}$, M. Ayub Ali ${ }^{1}$, L. Inaotombi Devi² ${ }^{2}$ Parthasarathi Behera ${ }^{1}$ and Lalsanglura Ralte ${ }^{2}$
}

1. Department of Veterinary Physiology and Biochemistry, College of Veterinary Sciences and A.H., Central Agricultural University, Selesih, Aizawl, Mizoram; 2. Department of Medical Laboratory Technology, Regional Institute of Paramedical and Nursing Sciences, Mizoram.

Corresponding author: Lalsangpuii,e-mail: docspee@gmail.com, MAA: ayubali1969@gmail.com, LD: linaotombi@gmail.com,PB: partha_vet@yahoo.co.in, LR: Lalralte@gmail.com

Received: 31-05-2015, Revised: 15-10-2015, Accepted: 25-10-2015, Published online: 11-12-2015

doi: 10.14202/vetworld.2015.1375-1378 How to cite this article: Lalsangpuii, Ali MA, Devi LI, Behera P, Ralte L (2015) Effect of age and season on the thyroid hormone activity of Mizoram strain female mithun (Bos frontalis), Veterinary World 8(12): 1375-1378.

\begin{abstract}
Aim: The aim of the present study was to generate baseline data on the normal values of the thyroidhormone (TH) activity as well as their correlation with age and season.

Materials and Methods: Blood samples $(10 \mathrm{ml})$ were collected from jugular vein of 30 female mithun's of three different age groups viz. Calves (6 months to 1 year), heifer (1-3 years) and adult (above 3 years) during the three season's viz. Monsoon, winter and spring of a year. The serum was analyzed for thyroid stimulating hormone (TSH), triiodothyronine $\left(\mathrm{T}_{3}\right)$, and thyroxine $\left(\mathrm{T}_{4}\right)$ activity.

Result: The result showed a significantly $(\mathrm{p}<0.05)$ a higher $\mathrm{T}_{3}$ level in heifers followed by adults and calves and higher $\mathrm{T}_{4}$ level in adults followed by heifers and calves in all the seasons. The TSH level was higher in heifers in all the seasons. The winter season recorded higher level of $\mathrm{T}_{3}, \mathrm{~T}_{4}$, and TSH as compared to the other seasons of a year.

Conclusion: The TSH and $\mathrm{T}_{3}$ level were the highest for aheifer, whereas $\mathrm{T}_{4}$ level was the highest for adults inall the season. Furthermore, the higher level of TH was observed in winter season. The increased level of the TH during the winter season signifies their calorigenic effect. Similarly in heifers, the increased $\mathrm{T}_{3}$ concentrations show its importance in reproductive physiology and its association with ovarian activity. This indicates that age and season have aprofound effect on TH activity of Mizoram strain female mithun.
\end{abstract}

Keywords: age, mithun, triiodothyronine, thyroxine, thyroid hormone, season.

\section{Introduction}

Mithun (Bos frontalis), is a semi-wild ruminant found in the north-eastern hilly regions of India besides Myanmar, Bhutan, Bangladesh, China, and Malaysia. They are the mainstay of meat production system in the north-eastern India. This bovine species is believed to be domesticated for more than 8000 years [1] from wild Gaur (Bos gaurus). Mizoram is home to $0.73 \%$ (1939) of mithun in India (18 ${ }^{\text {th }}$ Livestock census 2007) and is mostly concentrated in Champhai and Saiha districts.

The thyroid gland, one of the largest endocrine glands, plays an important role in the body metabolism through its secretions viz. triiodothyronine $\left(\mathrm{T}_{3}\right)$ and thyroxine $\left(\mathrm{T}_{4}\right)$. These thyroid hormones $(\mathrm{TH})$ are iodinated derivatives of the amino acid tyrosine [2] and are involved in the metabolic response of animals to certain nutritional, environmental and/or disease-relatedchallenges, as well as in regulation of certain ovarian functions[3]. However, the majority of $\mathrm{T}_{3}$ is derived from partial deiodination of $\mathrm{T}_{4}$ rather than the thyroid gland, and thus $\mathrm{T}_{3}$ is considered

Copyright: The authors. This article is an open access article licensed under the terms of the Creative Commons Attributin License (http:// creative commons.org/licenses/by/2.0) which permits unrestricted use, distribution and reproduction in any medium, provided the work is properly cited. biologically more active than $\mathrm{T}_{4}$ [4]. In animals, $\mathrm{TH}$ is required for normal growth and development indicating a pivotal role in growth regulation. Since they are necessary for normal growth; optimal concentrations of TH act as growth stimulators [5].

The thyroid hormones are the central regulators of energy metabolism [6]. These hormones are the primary endocrine stimulators of non-shivering ("facultative" or "adaptive") thermogenesis, thus regulating body temperature. They stimulate expression and activity of uncoupling proteins (UCPs), which uncouple re-oxidation of reduced coenzymes to ADP phosphorylation, hence producing heat [7]. A major exogenous regulator of thyroid gland activity is the environmental temperature. During heat stress, blood $\mathrm{T}_{3}$, and $\mathrm{T}_{4}$ concentrations, as well as metabolic rate, feed intake, growth and milk production are decreased [8-10]. The seasonal pattern of blood $\mathrm{TH}$ levels often showed maximal values during winter (cold months) and minimal during summer (hot months) $[11,12]$. Seasonal variation in plasma concentration of TH was reported in camel [6], cattle [13], buffaloes [12,14], and in goats [15].

Until date, only a few studies have been documented regarding hormonal profile $[16,17]$ of mithun. However, to the best of our knowledge there are no previous reports regarding the effect of age and season 
on TH activity of Mizoram strain female mithun. Keeping this in view, the present study was done to find out the serum TH activity and their relationship with age and season.

\section{Materials and Methods}

\section{Ethical approval}

The study was carried out after the approval from Institute Animal Ethics Committee (IAEC) of College of Veterinary Sciences \& Animal Husbandry, Central Agricultural University, Aizawl, Mizoram.

\section{Sample collection}

A total of 90 blood samples (10 blood samples each) of female mithun at different age groups viz. Calves ( 6 months to $<1$ year of age), heifers (from 1 year to $<3$ years), and adults (3 years and above) were collected at random from different mithun farmers' holdings located in Champhai and Saiha districts of Mizoram. The blood samples were collected in three different seasons (monsoon, winter, and spring) of a year. Approximately, $10 \mathrm{ml}$ venous blood from each mithun was collected from jugular vein using syringes with $18 \mathrm{G} 1.5$ hypodermic needles.

\section{Serum extraction and processing}

Immediately after collection, the blood samples were transferred into $15 \mathrm{ml}$ centrifuge tubes without anticoagulant and kept in a slanting manner for $1 \mathrm{~h}$ at room temperature for coagulation. The serums were separated by centrifugation at $2500 \mathrm{rpm}$ for $10 \mathrm{~min}$ and collected in sterile screw capped cryo-vials immediately and were transported to the research laboratory of Veterinary Physiology and Biochemistry Department, College of Veterinary Sciences and A.H., CAU, Selesih, Aizawl on ice. The serum sample were processed immediately for $\mathrm{TSH}, \mathrm{T}_{3}$, and $\mathrm{T}_{4}$ level by a MicroplateImmunoenzymometric Assay method using diagnostic kit (M/s RFCL Limited, Dehradun) as per the manufacturer's instruction by measuring the absorbance at $450 \mathrm{~nm}$ in a Thermo ELISA plate reader.

\section{Statistical analysis}

The data were analyzed by ANOVA and were found to be statistically significant at $\mathrm{p}<0.05$.

\section{Results}

The concentrations of serum thyroid-stimulating hormones (TSH), $\mathrm{T}_{3}$ and $\mathrm{T}_{4}$ are presented in Table-1. The levels of serum TSH, $\mathrm{T}_{3}$, and $\mathrm{T}_{4}$ differed significantly among the different age groups. Critical difference (CD) test revealed that significantly highest TSH level $(0.34 \pm 0.09)$ was observed in heifer followed by calves and the lowest value $(0.22 \pm 0.05)$ in adults (Figure-1) and for $\mathrm{T}_{3}$, significantly highest value $(1.92 \pm 0.21 \mathrm{ng} / \mathrm{dl})$ was observed in heifers, whereas, the calves depicted the lowest value $(1.27 \pm 0.19 \mathrm{ng} / \mathrm{dl})$ (Figure-2). However, the serum $\mathrm{T}_{4}$ level was found to increase with theage of the animal in all seasons. The serum $\mathrm{T}_{4}$ level ranged between $2.32 \pm 0.30(\mu \mathrm{g} / \mathrm{dl})$ and $4.08 \pm 0.29(\mu \mathrm{g} / \mathrm{dl})$, and the significantly highest level
$(3.66 \pm 0.55 \mu \mathrm{g} / \mathrm{dl})$ was observed in adults, whereas the lowest value $(2.41 \pm 0.30 \mu \mathrm{g} / \mathrm{dl})$ was observed in calves (Figure-3).

Table-1: Serum TSH, $\mathrm{T}_{3}$, and $\mathrm{T}_{4}$ levels at different age and different seasons.

\begin{tabular}{|c|c|c|c|c|}
\hline \multirow[t]{2}{*}{ Season } & \multirow[t]{2}{*}{ Age } & \multicolumn{3}{|c|}{ Parameters } \\
\hline & & $\begin{array}{c}\text { TSH } \\
(\mu \mathrm{IU} / \mathrm{ml})\end{array}$ & $\begin{array}{c}\mathrm{T}_{3} \\
(\mathrm{ng} / \mathrm{ml})\end{array}$ & $\begin{array}{c}\mathbf{T}_{4} \\
(\mu \mathrm{g} / \mathrm{dl})\end{array}$ \\
\hline \multirow[t]{3}{*}{ Monsoon } & Adult & $0.22 \pm 0.05^{\mathrm{bB}}$ & $1.54 \pm 0.15^{\mathrm{aB}}$ & $3.66 \pm 0.55^{\mathrm{aA}}$ \\
\hline & Heifer & $0.37 \pm 0.09^{a A}$ & $1.92 \pm 0.21^{\mathrm{A}}$ & $2.95 \pm 0.35^{\mathrm{B}}$ \\
\hline & Calves & $0.36 \pm 0.03^{\mathrm{aA}}$ & $1.27 \pm 0.19^{\mathrm{bc}}$ & $2.45 \pm 0.29^{c}$ \\
\hline \multirow[t]{3}{*}{ Winter } & Adult & $0.25 \pm 0.05^{\mathrm{aB}}$ & $1.77 \pm 0.14^{\mathrm{aA}}$ & $4.08 \pm 0.29^{\mathrm{aA}}$ \\
\hline & Heifer & $0.37 \pm 0.09^{a A}$ & $1.96 \pm 0.35^{\mathrm{A}}$ & $2.90 \pm 0.23^{B}$ \\
\hline & Calves & $0.35 \pm 0.04^{\mathrm{aA}}$ & $1.42 \pm 0.15^{\mathrm{aB}}$ & $2.32 \pm 0.30^{c}$ \\
\hline \multirow[t]{3}{*}{ Spring } & Adult & $0.21 \pm 0.03^{\mathrm{bB}}$ & $1.66 \pm 0.14 \mathrm{aB}$ & $3.11 \pm 0.24^{\mathrm{bA}}$ \\
\hline & Heifer & $0.27 \pm 0.04^{\mathrm{bA}}$ & $1.95 \pm 0.08^{\mathrm{A}}$ & $2.740 \pm 0.31^{\mathrm{B}}$ \\
\hline & Calves & $0.26 \pm 0.03^{\mathrm{bA}}$ & $1.21 \pm 0.16^{\mathrm{bc}}$ & $2.41 \pm 0.30^{C}$ \\
\hline
\end{tabular}

$\mathrm{TSH}=$ Thyroid stimulating hormone, $\mathrm{T}_{3}=$ Triiodothyronine, $\mathrm{T}_{4}=$ Thyroxine, The means with different superscript in capital letters and small letters differs

significantly $(p<0.01)$ between the rows and columns

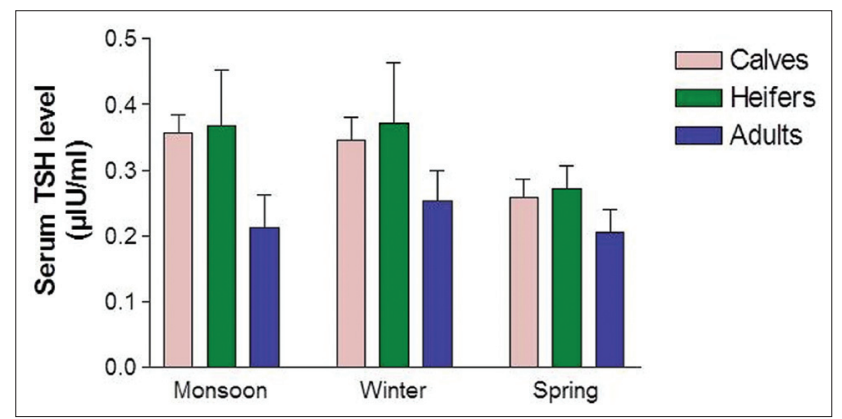

Figure-1: Serum thyroid stimulating hormone level at different age and seasons.

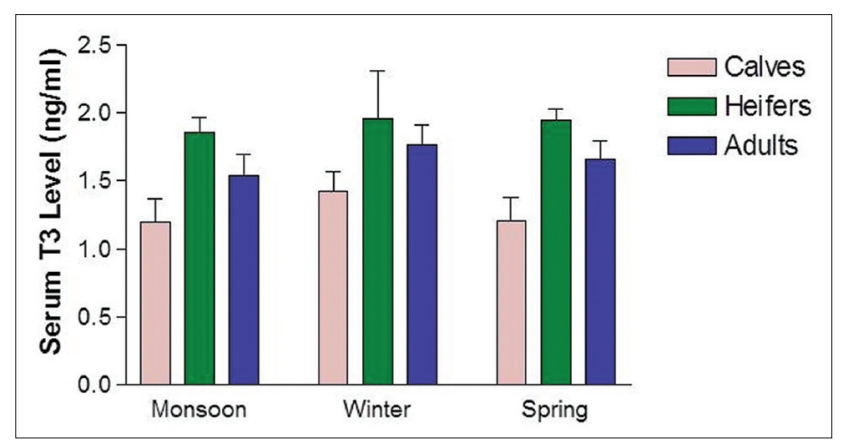

Figure-2: Serum triiodothyronine level at different age and seasons.

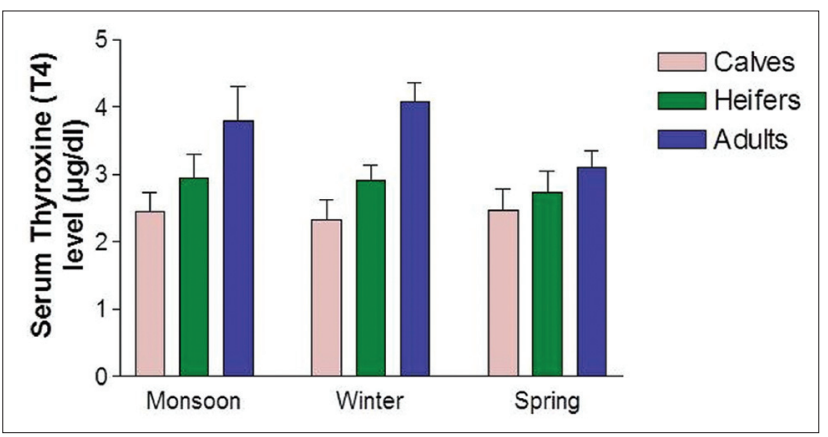

Figure-3: Serum thyroxine level at different age and seasons. 


\section{Discussion}

The TH play a key role in co-ordination of different factors involved in growth, which is of great economic importance as far as the livestock enterprises are concerned [5]. TH directly influence growth by altering biochemical reactions; and being anabolic hormones, cause positive nitrogen balance and promote growth and development [5]. In the present study, the TSH levels were lowest in calves and increases among the heifer and the level decreases in the adult. This shows that the TSH synthesis is inhibited by increasing circulatory levels of $\mathrm{T}_{3}$ and $\mathrm{T}_{4}$ in their respective ages. The synthesis of $\mathrm{TH}$ is regulated by feedback regulation. The increased synthesis of TSH occurs in response to decreased circulatory levels of $\mathrm{T}_{3}$ and $\mathrm{T}_{4}$. Among the different seasons of sample collection, the highest level of TSH was observed during monsoon and winter in all the age groups while the activity was decreased during spring. Similarly, the highest level of $\mathrm{T}_{3}$ was observed during the winter season. Seasonal variation in the heifers, however, was non-significant and for $\mathrm{T}_{4}$, the highest level was observed during the winter season.Bhullar et al. [18] have also reported the variation in plasma $T_{3}$ concentration in buffalo which is in agreement with our findings. Similar findings regarding $T_{3}$ level have been reported by Mayahi [11] in buffalo. The findings of Polat et al. [19] is also in line with our findings who observed decrease in $\mathrm{T}_{3}$ and $\mathrm{T}_{4}$ level with increase in temperature in case of white goats. The cold environment could be a stimulus to increase the thyrotrophic hormone output thereby resulting in a higher concentration of $\mathrm{TH}$ in serum. Zhang et al. [10] reported that during heat stress there was asignificant reduction in concentrations of $\mathrm{T}_{3}$ and $\mathrm{T}_{4}$ in plasma and in milk of lactating cows. The highest concentration of $\mathrm{T}_{3}$ was observed in heifers and then decreasing with advancing age in female Mithun is in accordance with Garg et al. [20]. The higher concentration of $\mathrm{T}_{3}$ in heifer could be one of the adaptive mechanisms to overcome the stressful period and subsequent declining trend could be attributed to the negative feedback mechanism exerted by already higher concentrations of $\mathrm{T}_{3}$ in blood. Besides, this increase in $\mathrm{T}_{3}$ secretion may also be due to higher TSH concentration or decreased $\mathrm{T}_{3}$ metabolic clearance due to low capability of $\mathrm{T}_{3}$ degrading enzymatic system in heifer. The serum $\mathrm{T}_{4}$ level was found to increase with age of the animals in all seasons. The serum $\mathrm{T}_{4}$ level in the present investigation ranged between $2.32 \pm 0.30$ and $4.08 \pm 0.29 \mu \mathrm{g} / \mathrm{dl}$.The overall mean values were found to differ significantly between the different age groups by applying CD test that revealed significantly the highest mean value in adults, followed by heifer and the lowest being in calves. The results are also in line with the finding of Ingole et al. [5] who reported a positive relationship between circulatory level of $\mathrm{TH}$ with age in buffaloes and in Jamunapari breeds of Goat [21].The observed increased level of the TH during the winter season signify the calorigenic effect and the processes and pathways mediating the intermediary metabolism of carbohydrates, lipids, and proteins are all affected by THs. Similarly in heifers, the increased $T_{3}$ and $T_{4}$ concentrations shows its importance in reproductive physiology and its association with ovarian activity. The slight high levels of $\mathrm{T}_{4}$ during prepubertal stage may be necessary for theenhanced synthesis of protein and gain in weight.Similar to the present study, Gray et al. [22] reported increase in $\mathrm{T}_{4}$ concentrations with age which is required precisely in regulated amounts for normal tissue growth process. Furthermore, the increase $\mathrm{T}_{4}$ levels have been proposed as one of the modes of action of estrogen to bring to cyclicity [20]. Moreover, Refesal et al.[23] observed in cows a significant herd and season interaction for both the $\mathrm{T}_{3}$ and $\mathrm{T}_{4}$ hormones. Similar to $\mathrm{T}_{3}$, Rasooli et al. [24] reported that in Holstein heifer, the serum concentration of $\mathrm{T}_{4}$ in summer was lower than in winter. $\mathrm{T}_{4}$ is a calorigenichormone and the thyroid activity is enhanced for maintaining constant body temperature by increasing the metabolic rate when exposed to thecold environment.

\section{Conclusions}

It can be concluded from the present study that the TSH and $\mathrm{T}_{3}$ level were highest for heifer whereas $\mathrm{T}_{4}$ level was the highest for adults inall the season. The increased level of the THs during the winter season signifies their calorigenic effect. Similarly in heifers, the increased $\mathrm{T}_{3}$ concentrations show its importance in reproductive physiology and its association with ovarian activity.

\section{Authors' Contributions}

LSP and MAA designed the experiment. LSP, MAA, and LID conducted the experimental work. LSP, MAA, PB and LSR were involved in scientific discussion and analysis of the data. LSP, MAA, and PB drafted and revised the manuscript. All authors read and approved the final manuscript.

\section{Acknowledgments}

The authors are thankful to the Dean, College of Veterinary Sciences \& A.H, C.A.U, Selesih for providing the necessary funds, facilities and Department of MLT, RIPANS, Mizoram for providing the necessary facilities for the current study.

\section{Competing Interests}

The authors declare that they have no competing interests.

\section{References}

1. Simoons, F.J. (1984) Gayal or mithun. In: Evolution of Domesticated Animals. I. L. Mason Edition, Longman, London.

2. Taylor, P.M. and Ritchie, J.W. (2007) Tissue uptake of thyroid hormone by amino acid transporters. Best.Pract. Res. Clin.Endocrinol.Metab. 21(2): 237-251.

3. Huszenicza, G.Y., Kulcsar, M. and Rudas, P. (2002) Clinical 
endocrinology of thyroid gland functions in ruminants. Vet. Med.Czech., 47(7): 199-210.

4. Tata, J.R. (2011) Looking for the mechanism of action of thyroid hormone. J ThyroidRes., 2011: Article ID: 730630, 12.

5. Ingole, S.D., Deshmukh, B.T., Nagvekar, A.S. and Bharucha, S.V. (2012) Serum profile of thyroid hormones from birth to puberty in buffalo calves and heifers. J.BuffaloSci., 1: 39-49.

6. Tajik, J., Sazmand, A., Hekmatimoghaddam, S. and Rasooli, A. (2013) Serum concentrationsof thyroid hormones, cholesterol and triglyceride, and their correlations together in clinically healthy camels (Camelusdromedarius): Effects of season, sex and age. Vet. Res. Forum., 4(4): 239-243.

7. Collin, A., Cassy, S., Buyse, J., Decuypere, E. and Damon, M. (2005) Potential involvement of mammalian and avian uncoupling proteins in the thermogenic effect of thyroid hormones. Domest. Anim. Endocrinol., 29: 78-87.

8. Marai, I.F.M. and Haeeb, A.A.M. (2010) Buffalo's biological functions as affected by heat stress - A review. Livest. Sci., 127:89-109.

9. Sunil Kumar, B.V., Kumar, A. and Kataria, M. (2011) Effect of heat stress in tropical livestock and different strategies for its amelioration. J. Stress Physiol. Biochem.,7(1): 45-54.

10. Zhang, L., Ying, S.J., An, W.J., Lian, H., Zhou, G.B. and Han, Z.Y. (2014) Effects of dietary betaine supplementation subjected to heat stress on milk performances and physiology indices in dairy cow. Genet. Mol. Res., 13(3): 7577-7586.

11. Abbas, H.H., Authman, M.M., Zahi, S.M. and Mohamed, G.F. (2012) Effect of seasonal temperature changes on thyroid structures and hormones secretion of white grouypers (Epinephelusaeneus) in Suez Gulf, Egypt. Life Sci., 9:2.

12. Mayahi, S., Mamouei, M., Tabatabaei, S. and Mirzadeh, K. (2014) Reproductive characteristics and thyroidal function in relation with season in Khuzestan buffalo (Bubalusbubalis) bulls. Vet. Res. Forum., 5(3): 201-205.

13. Saber, A.P.R., Jalali, M.T., Mohjeri, D., Akhoole, A.A., Teymourluei, H.Z.N., Nouri, M. and Garachorlo, S. (2009)
The effect of ambient temperatures on thyroid hormone concentration and histopathological changes of thyroid gland in cattle in Tabriz, IRAN. Asian J. Anim. Vet. Adv., 4(1): 28-33.

14. Aggarwal, A. and Singh, M. (2010) Hormonal changes in heat stressed Murrah buffaloes under two different cooling systems. Buffalo Bull., 29:1.

15. Todini, L. (2007) Thyroid hormones in small ruminants; effects of endogenous, environmental and nutritional factors. Anim., 1: 997-1008.

16. Mondal, M., Dhali, A., Rajkhowa, C. and Prakash, B.S. (2004) Secretion patterns of growth hormone in growing captive mithuns (Bosfrontalis). Zoolog. Sci., 21: 1125-1129.

17. Mondal, M., Dhali, A., Prakash, B., Rajkhowa, C. and Prakash, B.S. (2005) Development and the validation of a simple, sensitive, second antibody format enzyme immunoassay (EIA) for LH determination in mithun (Bosfrontalis). J. Immunoassay. Immunochem., 26: 157-167.

18. Bhullar, P., Nayyar, S. and Sangha, S.P.S. (2009), Antioxidant status and metabolic profile of buffalo during different growth stages. Indian J. Anim. Sci., 79(3): 251-254.

19. Polat, H., Dellal, G., Baritei, I. and Pehlivan, E. (2014) Changes of thyroid hormones in different physiological periods in white goats. J. Anim. Plant Sci., 24(2): 445-449.

20. Garg, S.L., Sharma, S., Rose, M.K.and Agarwal, V.K. (2002) Age associated. Indian J. Anim. Sci.,72(7): 579-581.

21. Bhooshan, N., Kumar, P., Singh, S.K. and Yadav, M.C. (2010) Status of thyroid hormones in blood plasma of goats at different ages and their correlation with other biochemical parameters. Indian J. Anim. Sci., 80(7): 634-637.

22. Gray, D.G., Unruh, J.A., Dikeman, M.E. and Stevenson, J.S. (1986) Implanting young bulls. J. Anim. Sci., 63: 747-756.

23. Refesal, K.R., Nachreiner, R.F. and Anderson, C.R. (1981) Effects of age, lactation. Pregnancy and season on serum T4 and T3 in Holstein cows. J. Anim. Sci., 53(1): 360-361.

24. Rasooli, A., Nouri, M., Khadjeh, G.H. and Rasekh, A. (2004) The influences of seasonal variations on thyroid activity and some biochemical parameters of cattle. Iran. J. Vet.Res., 5(10): 1383-1390.

\section{$* * * * * * * *$}

